
ISSN : 2615-1995, E-ISSN : 2615-0654

J. Madani., Vol. 3, No. 1, Maret 2020 (151 - 163)

(C)2018 Lembaga Kajian Demokrasi

dan Pemberdayaan Masyarakat (LKD-PM)

DOI : https://doi.org/10.33753/madani.v3i1.105

\title{
Pengaruh Gaya Kepemimpinan dan Jabatan Fungsional Perekayasa Terhadap Kinerja Pegawai Balai Besar Aerodinamika, Aeroelastika, dan Aeroakustika BPPT, Setu, Tangerang Selatan
}

\author{
Didi Sunardi \\ Fakultas Ekonomi, Universitas Pamulang \\ dosen00724@unpam.ac.id
}

\begin{abstract}
Abstrak
Tujuan daripenelitian ini adalah untuk mengetahui pengaruh gaya kepemimpinan dan karir jabatan fungsional perekayasa terhadap kinerja pegawai BBTA3 BPPT. Variabel yang diteliti adalah gaya kepemimpinan dan karir jabatan fungsional perekayasa sebagai variabel bebas dan kinerja pegawai sebagai variabel terikat. Metode penelitian yang dilakukan dalam penelitian ini adalah Asosiatif kuantitatif, data yang digunakan adalah hasil kuisioner dari pegawai BBTA3 BPPT. Data tersebut kemudian dianalisis dengan menggunakan metode koefisien korelasi, determinasi dan uji $t_{\text {hitung }}$ dan $F_{\text {hitung }}$ kemudian dibandingkan dengan $t_{\text {tabel }}$ dan $F_{\text {tabel }}$ Hasil penelitian menunjukan bahwa gaya kepemimpinan BBTA3 BPPT di Setu Tangerang Selatan dapat dikatakan baik, karena nilai rata-rata keseluruhan sebesar 3,91 berada pada interval 3,40 - 4,19, dan karir jabatan fungsional perekayasa dapat dikatakan baik, karena nilai rata-rata keseluruhan sebesar 3,81 berada pad interval 3,40-4,19. Sedangkan kinerja pegawai dapat dikatakan baik, karena nilai rata-rata keseluruhan sebesar 4,19 berada pada interval 3,40 - 4,19. Hasil koefisien korelasi (r) sebesar 0.394 dapat disimpulkan adanya pengaruh antara variabel $X_{1}$ (gaya kepemimpinan) $X_{2}$ Karir Jabatan Fungsional Perekayasa) terhadap variabel $Y$ (kinerja pegawai) dimana hubungan tersebut positif. Hasil perhitungan harga $F_{\text {hitung }}$ sebesar 5.923 selanjutnya dikonsultasikan dengan $F_{\text {tabel }}$ dengan $d k$ pembilang $=k$, dan $d k$ penyebut $=(n-k-1)$ dengan taraf kesalahan $5 \%$ maka didapat $F_{\text {tabel }}=3.14$. Ketentuan yang berlaku untuk $F_{\text {hitung }}$ lebih besar dari $F_{\text {tabel }}(5.923$ > 3.14) maka dapat dinyatakan bahwa korelasi ganda tersebut signifikan. Dengan demikian hipotesis nol $\left(H_{0}\right)$ yang menyatakan tidak terdapat pengaruh antara gaya kepemimpinan dan karir jabatan fungsional perekayasa terhadap kinerja pegawai ditolak, sedangkan hipotesis alternatif $\left(H_{a}\right)$ diterima.
\end{abstract}

Kata Kunci : Gaya Kepemimpinan, Jabatan Fungsional Perekayasa, Kinerja Pegawai

\begin{abstract}
The purpose of this study was to determine the effect of leadership style and functional career civil engineer on the performance of BBTA3-BPPT. The variables studied were the style of leadership and career engineer functional as independent variables and employee performance BBTA3-BPPT as the dependent variable. Design research conducted in the preparation of this thesis is Associative quantitative research that aims to determine the relationship between two or more variables describe or reveal a problem, situation, event or revealing facts as they are deeply and try to find a solution or solutions to problems. The data used is the result of the employee questionnaires BBTA3-BPPT. The data is then analyzed by using the correlation coefficient, determination and test $F_{\text {hitung }} t_{\text {hitung }}$ and then compared with $T_{\text {table }}$ and $F_{\text {table }}$. The results showed that leadership style BBTA3-BPPT in Setu Tangerang can be good, because the overall average value of 3.91 is in the interval 3.40 to 4.19, and engineer functional career can be good, because the value of overall average of 3.81 is pad interval from 3.40 to 4.19. While the performance of employees BBTA3-BPPT in southern Setu Tangerang can
\end{abstract}


be good, because the overall average value of 4.19 is the interval from 3.40 to 4.19 . The results of the correlation coefficient ( $r$ ) of 0394 can be summed up the effect of the variable $X_{1}$ (leadership style) $X_{2}$ (Functional Career Engineers) to variable $Y$ (employee performance) where the relationship is positive. The results of calculation for $5923 F_{\text {hitung }}$ further consultation with the $F_{\text {table }}$ with $d k=k$ numerator and denominator $d k=(n k-1)$ with a 5\% error level the importance of the $F_{\text {table }}=3.14$. Provisions applicable $F_{\text {hitung }}$ greater than $F_{\text {table }}(5923>3.14)$, it can be stated that the multiple correlation is significant. Thus the null hypothesis $\left(H_{0}\right)$ that states there is no effect between leadership styles and career engineer functional effect on employee performance is rejected, while the alternative hypothesis $\left(H_{a}\right)$ is accepted.

Keywords : Leadership, Functional Career Civil Engineer, Performance

\section{PENDAHULUAN}

Memasuki era perdagangan bebas, setiap perusahaan dituntut untuk dapat selalu meningkatkan daya saingnya agar bisa tangguh dan bertahan menghadapi persaingan. Dalam menjalankan suatu perusahaan maka aspek yang cukup penting adalah sumber daya manusia. Manusia selalu berperan aktif dan dominan dalam setiap kegiatan organisasi. Sebab manusia menjadi perencana, pelaku, dan penentu dalam terwujudnya tujuan organisasi.

Mengatur karyawan sangatlah sulit dan kompleks karena mereka mempunyai pikiran, perasaan, status, keinginan, dan latar belakang yang heterogen yang dibawa kedalam perusahaan. Di sinilah perlunya seorang pimpinan dalam perusahaan, bagaimana peran kepemimpinan dalam pengelolaan sumber daya manusia sehingga bisa mengintegrasikan antara keinginan perusahaan dan keinginan karyawan. Di samping peran dari pimpinan, peran sumber daya manusia sangatlah penting terutama pengembangan karir dan kenaikan jenjang dari karir pegawai memberikan pengaruh terhadap kinerja pegawai tersebut, baik itu karir struktural ataupun karir fungsional. Ada beberapa jalur fungsional yang ada di BBTA3BPPT, yaitu Fungsional Peneliti, Fungsional Perekayasa, Fungsional Litkayasa, Fungsional Arsiparis, Fungsional Analis Kepegawaian, dan Fungsional Pustakawan.

Perekayasa adalah jabatan yang mempunyai ruang lingkup, tugas, tanggung jawab, dan wewenang untuk melakukan kegiatan teknologi dalam suatu kelompok kerja fungsional pada bidang penelitian terapan, pengembangan, perekayasaan, dan pengoperasian yang diduduki oleh Pegawai
Negeri Sipil (PNS) dengan hak dan kewajiban yang diberikan secara penuh oleh pejabat yang berwenang. Perekayasaan adalah kegiatan penerapan ilmu pengetahuan dan teknologi dalam bentuk desain dan rancang bangun untuk menghasilkan sistem, model, nilai, produk dan atau proses produksi dengan mempertimbangkan keterpaduan sudut pandang dan atau konteks teknikal, fungsional, bisnis, sosial budaya, dan estetika, dalam suatu kelompok kerja fungsional.

Mengingat karyawan merupakan aset penting bagi perusahaan, banyak hal yang perlu diperhatikan dalam peningkatan kinerjanya. Kinerja adalah hasil kerja yang dicapai oleh individu sesuai dengan peran atau tugasnya dalam periode tertentu, yang dihubungkan dengan ukuran nilai atau standar tertentu dari organisasi tempat bekerja (Khaerul Umam, 2010: 188). Untuk itu kinerja merupakan kualitas dan kuantitas dari suatu hasil kerja (output) individu maupun kelompok dalam suatu aktivitas tertentu yang diakibatkan oleh kemampuan dan keinginan untuk berprestasi. Faktor-faktor yang mempengaruhi kinerja antara lain; faktor kemampuan (ability) pegawai baik kemampuan potensi dan kemampuan realita, faktor motivasi yang terbentuk dari sikap pegawai dalam menghadapi situasi pekerjaan, faktor mental yang mendorong seseorang untuk berusaha mencapai potensi kerja secara maksimal.

Sehubungan dengan uraian di atas maka penulis tertarik untuk mengadakan penelitian mengenai "Pengaruh Gaya Kepemimpinan dan Jabatan Fungsional Perekayasa Terhadap Kinerja Pegawai Balai Besar Teknologi Aerodinamika, Aeroelastika, dan Aeroakustika, Badan Pengkajian 
dan Penerapan Teknologi (BBTA3-BPPT), Setu, Tangerang Selatan".

\section{METODE}

Ada dua hal yang mempengaruhi kualitas data hasil penelitian, yaitu : kualitas instrumen penelitian dan kualitas pengumpulan data. Kualitas instrumen penelitian berkenaan dengan validitas dan reliabilitas instrumen dan kualitas pengumpulan data berkenaan ketepatan caracara yang digunakan untuk mengumpulkan data.

Penelitian dilakukan dengan mengumpulkan data yang dilakukan untuk kepentingan analisis dan pembahasan hasil penelitian dibedakan ke dalam dua bagian, yaitu data primer dan data sekunder. Data primer diperoleh dengan melakukan survei (penyebaran kuesioner kepada seluruh pegawai) dan wawancara dengan para pejabat yang ada berkenaan dengan gaya kepemimpinan dan pelaksanaan program kerja pimpinan BBTA3-BPPT. Sedangkan data sekunder dilakukan dengan cara mengumpulkan semua dokumen yang berkenaan dengan gaya kepemimpinan, pelaksanaan program kerja pimpinan BBTA3-BPP, jabatan fungsional perekayasa, dan kinerja pegawai, yang dijadikan bahan pengkajian secara kuantitatif dan kualitatif berupa :

\section{Populasi dan Sampel}

Penelitian ini merupakan penelitian sensus, yang melibatkan seluruh anggota populasi dalam hal ini adalah seluruh pegawai di BBTA3-BPPT, mulai dari staf hingga pimpinan puncak yang secara keseluruhan berjumlah 78 orang.

\section{Menguji Validitas dan Reliabilitas Instrumen}

Pengujian validitas instrumen dilakukan dengan cara mengkorelasikan antara skor butir pernyataan dengan total skor pernyataan. Rumus yang digunakan untuk pengujian validitas tersebut adalah korelasi product moment (Sugiyono, 2015: 212) yaitu :

$$
r x y=\frac{\sum x y}{\sqrt{\left(\sum x^{2}\right)\left(\sum y^{2}\right)}}
$$

$\mathrm{r} \quad=$ korelasi product moment yang dicari

$\mathrm{x}=$ skor butir pernyataan

$\mathrm{y}=$ total skor pernyataan

Hasil dari perhitungan dengan menggunakan rumus tersebut dinamakan $\mathrm{r}_{\text {hitung. }}$ Untuk mengatakan instrumen penelitian tersebut valid atau tidak, selanjutnya memakai rumus $t$, nilai $t_{\text {hitung }}$ dibandingkan dengan $t_{\text {tabel }}$ yang telah tersedia. Apabila $t_{\text {hitung }}$ lebih besar atau sama dengan $t_{\text {tabel }}$ instrumen penelitian dikatakan valid, sebaliknya jika $\mathrm{t}_{\text {hitung }}$ lebih kecil dari $\mathrm{t}_{\text {tabel }}$ maka instrumen penelitian tersebut tidak valid.

Untuk menguji reliabilitas instrumen digunakan teknik belah dua (split half) dari spearman brown (Sugiyono, 2015: 149) dengan rumus :

$$
\begin{aligned}
\mathrm{ri}= & \frac{2 r b}{1+r b} \\
\mathrm{ri}= & \text { reliabilitas internal seluruh instrumen } \\
\mathrm{rb}= & \text { korelasi product moment antara } \\
& \text { belahan pertama dan kedua }
\end{aligned}
$$

\section{Analisa Korelasi}

Yaitu suatu analisa yang digunakan untuk menunjukkan adanya hubungan/korelasi antara variabel yang satu dengan yang lainnya. Dalam penelitian ini variable $\mathrm{X}_{1}$ adalah gaya kepemimpinan, $\mathrm{X}_{2}$ jabatn fungsional perekayasa, sedangkan variabel y adalah kinerja karyawan BBTA3-BPPT.

Untuk menghitung koefisien korelasi (r) penulis menggunakan koefisien korelasi Product Moment, menurut (Sugiyono, 2015: 212) dengan rumusan sebagai berikut :

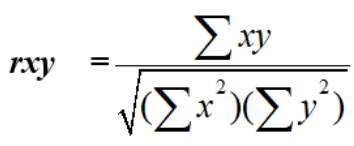

$$
\begin{aligned}
& \mathrm{x}=\text { Gaya kepemimpinan } \\
& \mathrm{y}=\text { Kinerja karyawan }
\end{aligned}
$$

Sementara itu, untuk dapat memberikan interpretasi keeratan pengaruh diperlukan adanya suatu pedoman untuk mendasarinya, seperti yang terlihat pada tabel di bawah ini : 
Pedoman untuk memberikan interpretasi terhadap koefisien korelasi :

\begin{tabular}{|c|c|}
\hline INTERVAL KORELASI & TINGKAT PENGARUH \\
\hline $0,00-0,19$ & Sangat rendah \\
\hline $0,20-0,39$ & Rendah \\
\hline $0,40-0,59$ & Sedang \\
\hline $0,60-0,79$ & Kuat \\
\hline $0,80-1,00$ & Sangat kuat \\
\hline & Sumber : Sugiyono, 2015:214 \\
\hline
\end{tabular}

\section{Analisa Koefisien Determinasi}

Metode ini digunakan untuk mengetahui berapa besar kontribusi dari variabel $\mathrm{x}$ terhadap naik turunnya variabel y dengan rumus menurut Supranto (2010: 146), yaitu :

$$
\mathrm{KP}=\mathrm{rs}^{2} \times 100 \%
$$

di mana :

$\mathrm{KP}=$ Koefisien penentu

rs $=$ Nilai koefisien korelasi

\section{Analisa Regresi}

Teknikanalisa ini dilakukan apabila hubungan kedua variabel yaitu variabel (x) dependen dan variabel (y) independen berupa hubungan kausal atau fungsional. Untuk menentukan kedua variabel mempunyai hubungan kausal atau tidak, maka harus didasarkan pada teori dan konsep tentang dua variabel tersebut (Sugiono, 2015: 237).

Persamaan umum regresi linier sederhana adalah :

$$
\begin{aligned}
& \mathbf{Y =} \mathbf{a}+\mathbf{b x} \\
& \begin{array}{ll}
\text { di mana : } \\
\mathrm{Y}= & \text { Variabel terikat yang nilainya di- } \\
& \text { pengaruhi variabel lainnya } \\
\mathrm{x} \quad= & \text { Variabel bebas yang nilainya tidak } \\
& \text { terikat pada variabel lain } \\
\mathrm{a} \quad= & \text { Konstanta } \\
\mathrm{b} \quad= & \text { Koefisien korelasi }
\end{array}
\end{aligned}
$$

\section{HASIL dan PEMBAHASAN}

Jumlah sampel yang dijadikan responden dalam penelitian ini adalah populasi yang berjumlah 78 orang. Instrumen yang digunakan untuk mengukur variabel gaya kepemimpinan menggunakan kuesioner dengan skala "Likert" di mana :

SS $=$ Sangat Setuju dengan nilai 5

$\mathrm{S}=$ Setuju dengan nilai 4

$\mathrm{R}$ = Ragu-ragu dengan nilai 3

TS = Tidak Setuju dengan nilai 2

STS $=$ Sangat Tidak Setuju dengan nilai 1

Kuesioner yang dipakai untuk mengukur variabel gaya kepemimpinan dapat diketahui bobot nilai tertinggi adalah 5 dan bobot terendah adalah 1. Untuk mengetahui range maka selisih antara bobot nilai tertinggi dan bobot terendah adalah $5-1=4$, untuk mengetahui jumlah interval kelas dan besar interval kelas dapat gunakan rumus menurut Sudjana (2015: 79) adalah sebagai berikut :

$$
\mathrm{P}=\frac{\text { rentang }}{\text { Banyak kelas interval }}
$$

$\mathrm{P}$

Rentang

Banyak kelas interval $=5$

Berdasarkan rumus tersebut, maka panjang interval adalah :

$$
\mathrm{P}=\frac{(5-1)}{5}=0,8
$$

Maka interval dari kriteria penilaian adalah sebagai berikut :

$$
\begin{aligned}
1,00-1,79 & =\text { Sangat tidak baik } \\
1,80-2,59 & =\text { Tidak baik } \\
2,60-3,39 & =\text { Kurang baik } \\
3,40-4,19 & =\text { Baik } \\
4,20-5,00 & =\text { Sangat baik }
\end{aligned}
$$

\section{Hasil}

\section{Deskripsi Data Gaya Kepemimpinan}

Berdasarkan data hasil penelitian dapat disimpulkan tanggapan responden mengenai gaya kepemimpinan BBTA3-BPPT Setu Tangerang Selatan dapat dikatakan baik, karena nilai rata-rata keseluruhan sebesar 3.91 berada pada interval $3,40-4,19$. Adapun nilai terendah terdapat pada pernyataan nomor 9 yang bernilai 3.70 Sedangkan nilai tertinggi terdapat pada pernyataan nomor 11 dengan nilai 4.22 dari keputusan tersebut 
dapat diketahui bahwa pimpinan BBTA3-BPPT dalam pengambilan keputusannya selalu mempertimbangan masukan-masukan dari bawahannya.

\section{Deskripsi Data Jabatan Fungsional}

Berdasarkan data hasil penelitian dapat disimpulkan tanggapan responden mengenai karir jabatan fungsional perekayasa BBTA3-BPPT Setu Tangerang Selatan dapat dikatakan baik, karena nilai rata-rata keseluruhan sebesar 3.81 berada pada interval 3,40 - 4,19 Adapun nilai terendah terdapat pada pernyataan nomor 11 yang bernilai 3.57 Sedangkan nilai tertinggi terdapat pada pernyataan nomor 1 dengan nilai 4.22 Dari keputusan tersebut dapat diketahui bahwa pegawai BBTA3-BPPT bersedia untuk berkarir dalam jabatan fungsional perekayasa.

\section{Deskripsi Data Kinerja}

Berdasarkan data hasil penelitian dapat disimpulkan tanggapan responden mengenai kinerja pegawai BBTA3-BPPT Setu Tangerang Selatan dapat dikatakan baik, karena nilai ratarata keseluruhan sebesar 4.19 berada pada interval 3,40 - 4,19, adapun nilai terendah terdapat pada pernyataan nomor 13 yang bernilai 3.62, sedangkan nilai tertinggi terdapat pada pernyataan nomor 1 dan 11 dengan nilai 4.57 dari keputusan tersebut dapat diketahui bahwa kinerja pegawai yang ada pada BBTA3-BPPT Setu Tangerang Selatan selama ini selalu bertindak jujur dan selalu berusaha untuk belajar dalam peningkatan kemampuan yang dapat menunjang pekerjaan.

\section{Pembahasan}

Sebelum melakukan pengujian terhadap hipotesis penelitian terlebih dahulu akan dilakukan beberapa pengujian terhadap instrumen penelitian, yaitu pengujian validitas instrumen dan pengujian reliabilitas instrumen.

\section{Pengujian Validitas dan Reliabilitas Instrumen}

Instrumen atau alat ukur dikatakan valid apabila dipergunakan untuk mengukur apa yang seharusnya diukur. Untuk mengetahui kevalidan suatu alat ukur dilakukan dengan cara mengkorelasikan jumlah skor butir pernyataan dengan skor total. Jika korelasi butir tersebut positif dan besarnya sama dengan atau lebih dari $\mathrm{r}_{\text {tabel }}$ untuk sampel maka instrumen atau alat ukur tersebut memiliki validitas yang baik (Sugiyono, 2015: 142).

Dalam penelitian ini instrumen yang dipergunakan adalah instrumen gaya kepemimpinan, karir jabatan fungsional perekayasa dan kinerja pegawai. Sebelum instrumen disusun dalam bentuk butir-butir pernyataan, terlebih dahulu disusun indikator-indikator dari variabel yang diteliti. Setiap variabel dikembangkan menjadi masing-masing 15 butir pernyataan.

Dari hasil perhitungan diketahui bahwa korelasi seluruh butir instrumen dengan skor total ditunjukkan pada tabel berikut berturut-turut instrumen untuk gaya kepemimpinan, karir jabatan fungsional perekayasa dan kinerja pegawai seperti di bawah ini:

Tabel 1. Hasil Perhitungan Pengujian Validitas Instrumen Variabel Gaya Kepemimpinan

\begin{tabular}{|c|c|c|c|}
\hline Butir Pernyataan ke & $r_{\text {hitung }}$ & $r_{\text {tabel }}$ & Keterangan \\
\hline 1 & 0.570 & 0.235 & Valid \\
\hline 2 & 0.656 & 0.235 & Valid \\
\hline 3 & 0.645 & 0.235 & Valid \\
\hline 4 & 0.659 & 0.235 & Valid \\
\hline 5 & 0.747 & 0.235 & Valid \\
\hline 6 & 0.629 & 0.235 & Valid \\
\hline 7 & 0.473 & 0.235 & Valid \\
\hline 8 & 0.681 & 0.235 & Valid \\
\hline 9 & 0.648 & 0.235 & Valid \\
\hline 10 & 0.623 & 0.235 & Valid \\
\hline 11 & 0.410 & 0.235 & Valid \\
\hline 12 & 0.675 & 0.235 & Valid \\
\hline 13 & 0.654 & 0.235 & Valid \\
\hline 14 & 0.680 & 0.235 & Valid \\
\hline 15 & 0.648 & 0.235 & Valid \\
\hline
\end{tabular}

Tabel 2. Hasil Perhitungan Pengujian Validitas Instrumen Variabel Karir Jabatan Fungsional Perekayasa

\begin{tabular}{|c|c|c|c|}
\hline Butir Pernyataan ke & $\mathbf{r}_{\text {hitung }}$ & $\mathbf{r}_{\text {tabel }}$ & Keterangan \\
\hline 1 & 0.655 & 0.235 & Valid \\
\hline 2 & 0.436 & 0.235 & Valid \\
\hline 3 & 0.780 & 0.235 & Valid \\
\hline 4 & 0.659 & 0.235 & Valid \\
\hline 5 & 0.763 & 0.235 & Valid \\
\hline
\end{tabular}




\begin{tabular}{|c|c|c|c|}
\hline 6 & 0.698 & 0.235 & Valid \\
\hline 7 & 0.711 & 0.235 & Valid \\
\hline 8 & 0.713 & 0.235 & Valid \\
\hline 9 & 0.518 & 0.235 & Valid \\
\hline 10 & 0.559 & 0.235 & Valid \\
\hline 11 & 0.780 & 0.235 & Valid \\
\hline 12 & 0.659 & 0.235 & Valid \\
\hline 13 & 0.763 & 0.235 & Valid \\
\hline 14 & 0.697 & 0.235 & Valid \\
\hline 15 & 0.598 & 0.235 & Valid \\
\hline
\end{tabular}

Tabel 3. Hasil Perhitungan Pengujian Validitas Instrumen
Variabel Kinerja Pegawai
\begin{tabular}{|c|c|c|c|}
\hline Butir Pernyataan ke & $\mathrm{r}_{\text {hitung }}$ & $\mathrm{r}_{\text {tabel }}$ & Keterangan \\
\hline 1 & 0.517 & 0.235 & Valid \\
\hline 2 & 0.658 & 0.235 & Valid \\
\hline 3 & 0.782 & 0.235 & Valid \\
\hline 4 & 0.793 & 0.235 & Valid \\
\hline 5 & 0.508 & 0.235 & Valid \\
\hline 6 & 0.554 & 0.235 & Valid \\
\hline 7 & 0.565 & 0.235 & Valid \\
\hline 8 & 0.423 & 0.235 & Valid \\
\hline 9 & 0.592 & 0.235 & Valid \\
\hline 10 & 0.497 & 0.235 & Valid \\
\hline 11 & 0.516 & 0.235 & Valid \\
\hline 12 & 0.658 & 0.235 & Valid \\
\hline 13 & 0.782 & 0.235 & Valid \\
\hline 14 & 0.793 & 0.235 & Valid \\
\hline 15 & 0.498 & 0.235 & Valid \\
\hline
\end{tabular}

Instrumen dikatakan reliabel (handal, konsisten) apabila instrumen tersebut menghasilkan data yang sama atas pengukuran yang dilakukan berulang-ulang pada obyek yang sama. Pengujian reliabilitas instrumen ini dilakukan dengan teknik belah dua (split half), dengan mengelompokkan instrumen menjadi dua kelompok yaitu kelompok instrumen ganjil dan instrumen genap.

Untuk mengukur tingkat reliabilitas instrumen penelitian digunakan rumus Spearman Brown, Sugiyono (2018:149) sebagai berikut :

$$
\begin{aligned}
\mathrm{ri} & =\frac{2 \mathrm{rb}}{1+\mathrm{rb}} \\
\mathrm{ri} & =\text { reliabilitas internal seluruh instrumen } \\
\mathrm{rb} & =\begin{array}{l}
\text { korelasi product moment antara } \\
\text { belahan pertama dan kedua }
\end{array}
\end{aligned}
$$

Dari hasil perhitungan untuk variabel gaya kepemimpinan didapat koefisien korelasi antara kelompok ganjil dan genap sebesar 0.864 , variabel karir jabatan fungsional perekayasa didapat koefisien korelasi antara kelompok ganjil dan genap sebesar 0.842 , variabel kinerja pegawai didapat koefisien korelasi antara kelompok ganjil dan genap sebesar 0.819 .

Nilai-nilai tersebut kemudian dimasukan ke dalam rumus Spearman Brown berikut ini,

$$
\begin{array}{cccc}
r i=\frac{2 \mathrm{rb}}{1+\mathrm{rb}} & r \mathrm{i}=\frac{2 * 0.864}{1+0.864} & r i=\frac{1.727}{1.864} & r i=\mathbf{0 . 9 3} \\
r \mathrm{i}=\frac{2 \mathrm{rb}}{1+\mathrm{rb}} & r \mathrm{i}=\frac{2 * 0.842}{1+0.842} & r \mathrm{i}=\frac{1.685}{1.842} & r \mathrm{i}=\mathbf{0 . 9 1} \\
r \mathrm{i}=\frac{2 \mathrm{rb}}{1+\mathrm{rb}} & r \mathrm{i}=\frac{2 * 0.819}{1+0.819} & r \mathrm{i}=\frac{1.638}{1.819} & r \mathrm{i}=\mathbf{0 . 9 0}
\end{array}
$$

Dari hasil perhitungan di atas dapat dilihat bahwa reliabilitas instrumen gaya kepemimpinan sebesar 0.93 , reliabilitas karir jabatan fungsional perekayasa sebesar 0.91 dan reliabilitas kinerja pegawai sebesar 0.90 .

\section{Pengujian Hipotesis Penelitian}

Setelah instrumen diuji validitas dan reliabilitasnya kemudian selanjutnya dilakukan pengujian hipotesis penelitian. Dalam penelitian ini diajukan tiga hipotesis, yaitu :

Diduga terdapat pengaruh positif dan signifikan secara parsial dari gaya kepemimpinan terhadap kinerja pegawai BBTA3-BPPT

Data-data untuk menghitung korelasi sederhana antara variabel gaya kepemimpinan dan kinerja pegawai tertera pada tabel 4.9 , dari data pada tabel 4.9 tersebut kemudian dimasukkan ke dalam rumus korelasi Product Moment sederhana sebagai berikut :

$$
\begin{aligned}
& r x y=\frac{\sum x y}{\sqrt{\left(\Sigma x^{2}\right)\left(\Sigma y^{2}\right)}} \\
& r x y=\frac{630.58}{\sqrt{(3498.81)(2752.81)}} \\
& r x y=\frac{630.58}{\sqrt{9632048}} \\
& r x y=\frac{630.58}{3103.554} \\
& r x y=0.20318
\end{aligned}
$$


Dari hasil perhitungan tersebut di atas terdapat pengaruh yang positif sebesar 0.203 antara gaya kepemimpinan dengan kinerja pegawai. Untuk memberikan interpelasi terhadap kuatnya hubungan tersebut dapat dilihat pada tabel interpelasi koefisien korelasi yaitu tabel 4 .

\begin{tabular}{|c|c|}
\hline \multicolumn{2}{|c|}{ Tabel 4. Pedoman untuk Memberikan Interpelasi Koefisien Korelasi } \\
\hline Internal Koefisien Korelasi & Tingkat Hubungan \\
\hline $0.00-0.199$ & Sangat Rendah \\
\hline $0.20-0.399$ & Rendah \\
\hline $0.40-0.599$ & Sedang \\
\hline $0.60-0.799$ & Kuat \\
\hline $0.80-1.000$ & Sangat Kuat \\
\hline & Sumber : Sugiyono $(2015,250)$ \\
\hline
\end{tabular}

Untuk melihat apakah harga koefisien korelasi yang didapat signifikan atau tidak apabila diterapkan untuk seluruh populasi yang berjumlah 78 orang, maka perlu diuji dengan menggunakan rumus $\mathrm{t}$ sebagai berikut :

$$
\begin{aligned}
& t=\frac{0.203 \sqrt{78-2}}{\sqrt{1-0.203^{2}}} \\
& t=\frac{0.203 * 8.717}{\sqrt{1-0.412}} \\
& t=\frac{1.770}{0.679} \\
& t=\mathbf{2 . 6 0 6}
\end{aligned}
$$

Harga $\mathrm{t}_{\text {hitung }}$ tersebut selanjutnya dibandingkan dengan harga $\mathrm{t}_{\text {tabel }}$ Untuk kesalahan 5\% dengan $\mathrm{dk}=\mathrm{n}-2(78-2)=76$, maka diperoleh $\mathrm{t}_{\text {tabel }}=2.606$. Karena $\mathrm{t}_{\text {hitung }}$ lebih besar dari harga $\mathrm{t}_{\text {tabel }}(2.606>$ 2.000), maka dapat disimpulkan bahwa pengaruh gaya kepemimpinan terhadap kinerja pegawai adalah signifikan. Dengan demikian hipotesis nol $\left(\mathrm{H}_{0}\right)$ yang menyatakan tidak terdapat pengaruh antara gaya kepemimpinan terhadap kinerja pegawai ditolak, sedangkan hipotesis altenatif $\left(\mathrm{H}_{\mathrm{a}}\right)$ diterima.

Untuk melihat seberapa besar pengaruh gaya kepemimpinan terhadap kinerja pegawai dapat dihitung dengan menggunakan persamaan koefisien determinasi dengan rumus sebagai be rikut :

$$
\begin{aligned}
\mathrm{KD} & =\mathrm{r}^{2} \times 100 \% \\
& =(0.203)^{2} \times 100 \% \\
& =0.041209 \times 100 \% \\
& =\mathbf{4 . 1 2} \%
\end{aligned}
$$

Dari hasil perhitungan koefisien determinasi tersebut di atas dapat diartikan bahwa pengaruh gaya kepemimpinan terhadap kinerja pegawai adalah sebesar $4.12 \%$ sisanya sebesar $95.88 \%$ ditentukan oleh faktor lain.

Untuk memprediksi seberapa besar nilai variabel kinerja pegawai berdasarkan nilai variabel gaya kepemimpinan digunakan analisis regresi sederhana sebagai berikut :

$$
\mathbf{Y}=\mathbf{a}+\mathbf{b X}
$$

Berdasarkan data pada tabel tersebut di atas $\left(\mathrm{N}=78, \Sigma \mathrm{X}=4049, \Sigma \mathrm{Y}=4330, \Sigma \mathrm{X}^{2}=3498.99\right.$, $\left.\sum \mathrm{Y}^{2}=2752.81, \sum \mathrm{XY}=630.58\right)$, maka untuk mengetahui nilai a adalah sebagai berikut :

$$
\begin{aligned}
& \boldsymbol{a}=\frac{\left(\sum \mathrm{Y}\right)\left(\sum \mathrm{X}^{2}\right)-\left(\sum \mathrm{X}\right)\left(\sum \mathrm{XY}\right)}{\mathrm{N} \sum \mathrm{X}^{2}-\left(\sum \mathrm{X}\right)^{2}} \\
& \boldsymbol{a}=\frac{(4330)(3498.99)-(4049)(630.58)}{78(3498.99)-(4049)^{2}} \\
& \boldsymbol{a}=\frac{(15150626.70)-(2553218.42)}{(272921.22)-(16394401)} \\
& \boldsymbol{a}=\frac{12597408.28}{\mathbf{- 1 6 1 2 1 4 7 9 . 7 8}} \\
& \boldsymbol{a}=\mathbf{- 0 . 7 8 1}
\end{aligned}
$$

Sedangkan untuk mengetahui nilai $\mathrm{b}$ digunakan rumus sebagai berikut :

$$
\begin{aligned}
& \boldsymbol{b}=\frac{N \sum \mathrm{XY}-\left(\sum \mathrm{X}\right)\left(\sum \mathrm{Y}\right)}{N \sum \mathrm{X}^{2}-\left(\sum \mathrm{X}\right)^{2}} \\
& \boldsymbol{b}=\frac{78(630.58)-(4049)(4330)}{78(3498.99)-(4049)^{2}} \\
& \boldsymbol{b}=\frac{49185.24-17532170}{(272921.22)-(16394401)} \\
& \boldsymbol{b}=\frac{-17482985}{-16121480} \\
& \boldsymbol{b}=\mathbf{1 . 0 8 4}
\end{aligned}
$$

Dari hasil perhitungan regresi tersebut di atas, maka persamaan regresi gaya kepemimpinan dan kinerja pegawai adalah $\mathrm{Y}=-0.779 \times 1.084 \mathrm{X}$. Nilai tersebut diartikan bahwa nilai kinerja pe- 
gawai dapat diprediksikan apabila nilai gaya kepemimpinan ditetapkan. Misalnya nilai gaya kepemimpinan (X) akan dinaikan sampai dengan nilai optimal. Nilai optimal adalah nilai ideal tiap butir instrumen dikalikan dengan jumlah butir instrumen. Untuk variabel gaya kepemimpinan nilai idealnya adalah $5 \times 15=75$, maka kinerja pegawai akan menjadi $\mathbf{Y}=-\mathbf{0 . 7 7 9}+(\mathbf{1 . 0 8 4})(\mathbf{7 5})$ $=81.299$.

Diduga terdapat pengaruh positif dan signifikan secara parsial dari jabatan fungsional perekayasa terhadap kinerja pegawai BBTA3-BPPT

Data-data untuk menghitung korelasi sederhana antara variabel karir jabatan fungsional perekayasa dan kinerja pegawai tertera pada tabel 4.11. Dari data pada tabel 4.11 tersebut kemudian dimasukkan ke dalam rumus korelasi Product Moment sederhana sebagai berikut :

$$
\begin{aligned}
& r x y=\frac{\sum x y}{\sqrt{\left(\sum x^{2}\right)\left(\sum y^{2}\right)}} \\
& r x y=\frac{1345.39}{\sqrt{(4886.96)(2752.81)}} \\
& r x y=\frac{1345.39}{\sqrt{13452870.57}} \\
& r x y=\frac{1345.39}{3667.815} \\
& r x y=0.36681
\end{aligned}
$$

Dari hasil perhitungan terdapat pengaruh yang positif sebesar 0.367 antara karir jabatan fungsional perekayasa terhadap kinerja pegawai. Untuk memberikan interpelasi terhadap kuatnya hubungan tersebut dapat dilihat pada tabel interpelasi koefisien korelasi yaitu tabel 4 .

Untuk melihat apakah harga koefisien korelasi yang didapat signifikan atau tidak apabila diterapkan untuk seluruh populasi yang berjumlah 69 orang, maka perlu diuji dengan menggunakan rumus $t$ sebagai berikut :

$$
\begin{aligned}
t & =\frac{r \sqrt{n-2}}{\sqrt{1-r^{2}}} \\
t & =\frac{0.367 \sqrt{69-2}}{\sqrt{1-0.367^{2}}}
\end{aligned}
$$

$$
\begin{aligned}
t & =\frac{0.367 * 8.185}{\sqrt{1-0.13455}} \\
t & =\frac{3.0025}{0.9302} \\
t & =\mathbf{3 . 2 2 7}
\end{aligned}
$$

Harga $\mathrm{t}_{\text {hitung }}$ tersebut selanjutnya dibandingkan dengan harga $\mathrm{t}_{\text {tabel }}$. Untuk kesalahan $5 \%$ dengan $\mathrm{dk}=\mathrm{n}-2(78-2)=76$, maka diperoleh $\mathrm{t}_{\text {tabel }}=2.000$. Karena $\mathrm{t}_{\text {hitung }}$ lebih besar dari harga $\mathrm{t}_{\text {tabel }}(3.227>$ 2.000), maka dapat disimpulkan bahwa pengaruh karir jabatan fungsional perekayasa terhadap kinerja pegawai adalah signifikan. Dengan demikian hipotesis nol $\left(\mathrm{H}_{0}\right)$ yang menyatakan tidak terdapat pengaruh antara karir jabatan fungsional perekayasa dan kinerja karyawan ditolak, sedangkan hipotesis altenatif $\left(\mathrm{H}_{\mathrm{a}}\right)$ diterima.

Untuk melihat seberapa besar pengaruh karir jabatan fungsional perekayasa terhadap kinerja pegawai dapat dihitung dengan menggunakan persamaan koefisien determinasi dengan rumus sebagai berikut :

$$
\begin{aligned}
\mathrm{KD} & =\mathrm{r}^{2} \times 100 \% \\
& =(0.367)^{2} \times 100 \% \\
& =0.13455 \times 100 \% \\
& =13,45 \%
\end{aligned}
$$

Dari hasil perhitungan koefisien determinasi tersebut di atas dapat diartikan bahwa pengaruh karir jabatan fungsional perekayasa terhadap kinerja pegawai adalah sebesar $13,45 \%$ sisanya sebesar 86,55 \% ditentukan oleh faktor lain.

Untuk memprediksi seberapa besar nilai variabel kinerja pegawai berdasarkan nilai variabel karir jabatan fungsional perekayasa digunakan analisis regresi sederhana sebagai berikut :

$$
\mathbf{Y}=\mathbf{a}+\mathbf{b X}
$$

Berdasarkan data pada tabel tersebut di atas $\left(\mathrm{N}=78, \Sigma \mathrm{X}=3963, \Sigma \mathrm{Y}=4330, \sum \mathrm{X}^{2}=4886.96\right.$, $\left.\sum \mathrm{Y}^{2}=2752.81, \sum \mathrm{XY}=1345.39\right)$, maka untuk mengetahui nilai a adalah sebagai berikut:

$$
\begin{aligned}
& \boldsymbol{a}=\frac{\left(\sum \mathrm{Y}\right)\left(\sum \mathrm{X}^{2}\right)-\left(\sum \mathrm{X}\right)\left(\sum \mathrm{XY}\right)}{\mathrm{N} \sum \mathrm{X}^{2}-\left(\sum \mathrm{X}\right)^{2}} \\
& \boldsymbol{a}=\frac{(4330)(4886.96)-(3963)(1345.39)}{78(4886.96)-(3963)^{2}}
\end{aligned}
$$




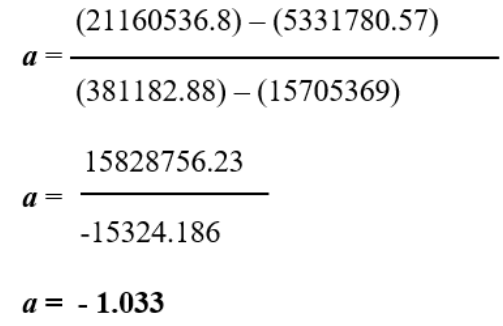

Sedangkan untuk mengetahui nilai $\mathrm{b}$ digunakan rumus sebagai berikut :

$$
\begin{aligned}
& \boldsymbol{b}=\frac{N \sum \mathrm{XY}-\left(\sum \mathrm{X}\right)\left(\sum \mathrm{Y}\right)}{N \sum \mathrm{X}^{2}-\left(\sum \mathrm{X}\right)^{2}} \\
& \boldsymbol{b}=\frac{78(1345.39)-(3963)(4330)}{78(4886.96)-(3963)^{2}} \\
& \boldsymbol{b}=\frac{104940.42-17159790}{(381182.88)-(15705369)} \\
& \boldsymbol{b}=\frac{-17054850}{-15324184} \\
& \boldsymbol{b}=\mathbf{1 . 1 1 3}
\end{aligned}
$$

Dari hasil perhitungan regresi tersebut di atas, maka persamaan regresi karir jabatan fungsional perekayasa dan kinerja pegawai adalah $\mathrm{Y}=-1.030 \mathrm{x} 1.110 \mathrm{X}$. Nilai tersebut diartikan bahwa nilai kinerja pegawai dapat diprediksikan apabila nilai karir jabatan fungsional perekayasa ditetapkan. Misalnya nilai karir jabatan fungsional perekayasa (X) akan dinaikan sampai dengan nilai optimal. Nilai optimal adalah nilai ideal tiap butir instrumen dikalikan dengan jumlah butir instrumen. Untuk variabel karir jabatan fungsional perekayasa nilai idealnya adalah $5 \mathrm{x}$ $15=75$, maka kinerja pegawai akan menjadi $\mathrm{Y}=$ $-1.030+(1.110)(75)=82.22$

Diduga terdapat pengaruh positif dan signifikan secara simultan gaya kepemimpinan dan jabatan fungsional perekayasa terhadap kinerja pegawai BBTA3-BPPT

Setelah hipotesis 1 dan 2 diuji dan data korelasinya telah diketahui, maka langkah selanjutnya adalah menguji hipotesis 3 seperti tersebut di atas dengan menggunakan rumus korelasi Product Moment ganda, menurut Sugiyono (2010:222) dengan rumusan sebagai berikut :

$$
\begin{aligned}
\operatorname{Ryx}_{1} x_{2}= & \sqrt{\frac{r^{2} y x_{1}+r^{2} y x_{2}-2 r_{y x_{1}} r_{y x 2} r_{x 1 x 2}}{1-r_{x 1 x^{2}}}} \\
\operatorname{Ryx}_{1} \mathrm{x}_{2}= & \text { Korelasi antara variabel } \mathrm{X}_{1} \\
& \begin{array}{l}
\text { dengan } \mathrm{X}_{2} \text { secara bersama- sama } \\
\text { dengan variabel Y }
\end{array} \\
= & \text { Korelasi Product Moment antara } \\
\text { ryx }_{1} & \mathrm{X}_{1} \text { dengan Y } \\
\text { ryx }_{2}= & \text { Korelasi Product Moment antara } \\
& \mathrm{X}_{2} \text { dengan Y } \\
\operatorname{rx}_{1} \mathrm{x}_{2}= & \text { Korelasi Product Moment antara } \\
& \mathrm{X}_{1} \text { dengan } \mathrm{X}_{2}
\end{aligned}
$$

Sebagaimana diketahui bahwa harga ryx $_{1}=$ 0.203, ryx $_{2}=0.327$ dan ry $\mathrm{x}_{1} \mathrm{x}_{2}=0.825$ kemudian harga-harga tersebut dimasukkan kedalam rumus korelasi Product Moment ganda menjadi sebagai berikut :

$$
\begin{aligned}
R y x_{1} x_{2} & =\sqrt{\frac{(0.203)^{2}+(0.327)^{2}-2(0.203)(0.825)}{1-0.825^{2}}} \\
R y x_{1} x_{2} & =\sqrt{\frac{0.041+0.107-0.335}{1-0.681}} \\
R y x_{1} x_{2} & =\sqrt{\frac{0.148-0.335}{0.319}} \\
R y x_{1} x_{2} & =\sqrt{\frac{0.049}{0.319}} \\
R^{\prime} x_{1} x_{2} & =\sqrt{0.155} \\
R^{2} x_{1} x_{2} & =0.394
\end{aligned}
$$

Dari hasil perhitungan terdapat pengaruh yang positif sebesar 0.394 antara gaya kepemimpinan dan karir jabatan fungsional perekayasa secara bersama-sama terhadap kinerja pegawai. Untuk memberikan interpelasi terhadap kuatnya pengaruh tersebut dapat dilihat pada tabel interpelasi koefisien korelasi yaitu tabel 4 .

Untuk menguji tingkat signifikansi korelasi antara dua variabel bebas secara bersama-sama dengan variabel terikat tersebut di atas, menggunakan rumus sebagai berikut Sugiyono (2015: 222) :

$$
F h=\frac{R^{2} / k}{\left(1-R^{2}\right) /(n-k-1)}
$$

di mana :

Fh = Nilai signifikansi yang dicar

$\mathrm{R}=$ Koefisien korelasi ganda 
$\mathrm{k}=$ Jumlah variabel bebas

$\mathrm{n}$ = Jumlah anggota sampel (responden)

$$
F h=\frac{0.394^{2} / 2}{\left(1-0.394^{2}\right) /(78-2-1)}
$$

$$
\begin{aligned}
F h & =\frac{0.155 / 2}{(1-0.155) / 75} \\
F h & =\frac{0.077}{0.011} \\
F h & =7
\end{aligned}
$$

Dari hasil perhitungan di atas yaitu harga $\mathrm{F}_{\text {hitung }}$ sebesar 7 selanjutnya dikonsultasikan dengan $\mathrm{F}_{\text {tabel }}$. Dengan $\mathrm{dk}$ pembilang $=\mathrm{k}$, dan dk penyebut $=(n-k-1)$ dengan taraf kesalahn 5\% maka didapat $\mathrm{F}_{\text {tabel }}=3.14$. Ketentuan yang berlaku untuk $\mathrm{F}_{\text {hitung }}$ lebih besar dari $\mathrm{F}_{\text {tabel }}(7>3.14)$ maka koefisien korelasi ganda yang diuji adalah signifikan.

Untuk melihat seberapa besar pengaruh gaya kepemimpinan dan karir jabatan fungsional perekayasa secara bersama-sama terhadap kinerja pegawai dapat dihitung dengan menggunakan persamaan koefisien determinasi dengan rumus sebagai berikut :

$$
\begin{aligned}
\mathrm{KD} & =\mathrm{r}^{2} \times 100 \% \\
& =(0.394)^{2} \times 100 \% \\
& =0.155 \times 100 \% \\
& =15.52 \%
\end{aligned}
$$

Dari hasil perhitungan koefisien determinasi tersebut di atas dapat diartikan bahwa pengaruh gaya kepemimpinan dan karir jabatan fungsional perekayasa secara bersama-sama terhadap kinerja pegawai adalah sebesar $15.52 \%$ sisanya sebesar $84.48 \%$ ditentukan oleh faktor lain.

Untuk mengetahui bagaimana kualitas kinerja pegawai BBTA3-BPPT, kalau gaya kepemimpinan dan karir jabatan fungsional perekayasa secara bersama-sama ditingkatkan sampai dengan nilai optimal. Nilai optimal sesuai dengan skor ideal instrumen adalah $5 \times 15=75$ (5 adalah skor tertinggi dalam instrumen, 15 adalah butir instrumen). Untuk menganalisanya menggunakan analisis regresi ganda dengan rumus, Sugiyono (2015: 277) sebagai berikut :

$$
\mathbf{Y}=\mathbf{a}+\mathbf{b}_{1} \mathbf{X}_{1}+\mathbf{b}_{2} \mathbf{X}_{2}
$$

di mana :

\begin{tabular}{|c|c|c|c|}
\hline$\Sigma Y$ & $=4330$ & $\sum \mathrm{X}_{2} \mathrm{Y}$ & $=250038$ \\
\hline$X_{1}$ & $=4049$ & $\sum \mathrm{X}_{1} \mathrm{X}_{2}$ & 235966 \\
\hline $\mathrm{X}_{2}$ & $=3963$ & $\mathrm{X}_{1}^{2}$ & $=241099$ \\
\hline $\mathrm{Y}$ & $=254720$ & $\mathrm{X}_{2}^{2}$ & 232 \\
\hline
\end{tabular}

$$
\begin{aligned}
\mathrm{Y}= & \text { Variabel terikat yang nilainya } \\
& \text { dipengaruhi variabel lainnya } \\
\mathrm{X}_{1}= & \text { Variabel bebas yang nilainya tidak } \\
& \text { terikat pada variabel lain } \\
\mathrm{X}_{2}= & \text { Variabel bebas yang nilainya tidak } \\
& \text { terikat pada variabel lain } \\
\mathrm{a}= & \text { Konstanta } \\
\mathrm{b}= & \text { Koefisien korelasi }
\end{aligned}
$$

Untuk menghitung harga-harga $a, b_{1}$ dan $b_{2}$ menggunakan persamaan sebagai berikut, Sugiyono $(2010: 279)$ :

$$
\begin{array}{lll}
\sum \mathrm{Y}=\mathrm{an} & +\mathrm{b}_{1} \sum \mathrm{X}_{1} & +\mathrm{b}_{2} \sum \mathrm{X}_{2} \\
\sum \mathrm{X}_{1} \mathrm{Y}=\mathrm{a} \sum \mathrm{X}_{1} & +\mathrm{b}_{1} \sum \mathrm{X}_{1}^{2} & +\mathrm{b}_{2} \sum \mathrm{X}_{1} \mathrm{X}_{2} \\
\sum \mathrm{X}_{2} \mathrm{Y}=\mathrm{a} \sum \mathrm{X}_{2} & +\mathrm{b}_{1} \mathrm{X}_{1} \mathrm{X}_{2} & +\mathrm{b}_{2} \sum \mathrm{X}_{2}^{2}
\end{array}
$$

Data mentah sebagai sumber perhitungan dengan menggunakan rumus di atas disajikan pada tabel 4.14 dengan nilai-nilai sebagai berikut :

Data-data tersebut dimasukan ke dalam rumus persamaan sebagai berikut :

$4330=78 a+4049 b_{1}+3963 b_{2}$
$254720=4049 a+241099 b_{1}+235966 b_{2}$
$250038=3963 a+235966 b_{1}+232501 b_{2}$

Dari persamaan tersebut di atas kemudian dibuat tabel seperti berikut :

\begin{tabular}{|c|c|c|c|c|}
\hline $\mathbf{a}$ & $\mathbf{b}_{\mathbf{1}}$ & $\mathbf{b}_{\mathbf{2}}$ & $\mathbf{Y}$ & Keterangan \\
\hline 69 & 4049 & 3963 & 4330 & Persamaan 1 \\
\hline 4049 & 241099 & 235966 & 254720 & Persamaan 2 \\
\hline 3963 & 235966 & 232501 & 250038 & Persamaan 3 \\
\hline \multicolumn{4}{|c|}{ Sumber : Sugiyono (2015: 279) } \\
\hline
\end{tabular}

Langkah selanjutnya adalah mengalikan harga pada persamaan (1) dengan $\sum X_{1}$ yaitu 4049, dan mengalikan harga persamaan (2) dengan jumlah sampel yaitu 78. Dari hasil perkalian tersebut akan dapat persamaan (4). Langkah tersebut adalah sebagai berikut :

\begin{tabular}{|c|c|c|c|c|}
\hline $\mathbf{a}$ & $\mathbf{b}_{1}$ & $\mathbf{b}_{2}$ & $\mathbf{Y}$ & Keterangan \\
\hline 279381 & 16394401 & 16046187 & 17532170 & Pers 1 x 4049 (a) \\
\hline 279381 & 16635831 & 16281654 & 17575680 & Pers 2 × 78 (B) \\
\hline 0 & -241430 & -235467 & -43510 & $\begin{array}{c}\text { Persamaan 4 } \\
\text { (a- B) }\end{array}$ \\
\hline \multicolumn{4}{|c|}{ Sumber : Sugiyono (2015: 280) } \\
\hline
\end{tabular}


Langkah berikutnya adalah mengalikan harga pada persamaan (1) dengan $\sum \mathrm{X}_{2}$ yaitu 3963 , dan mengalikan harga persamaan (3) dengan jumlah sampel yaitu 78. Dari hasil perkalian tersebut akan dapat persamaan (5). Langkah tersebut adalah sebagai berikut :

\begin{tabular}{|c|c|c|c|c|}
\hline $\mathbf{a}$ & $\mathbf{b}_{\mathbf{1}}$ & $\mathbf{b}_{\mathbf{2}}$ & $\mathbf{Y}$ & Keterangan \\
\hline 273447 & 16046187 & 15705369 & 17159790 & Pers 1 3963 (a) \\
\hline 273447 & 16281654 & 16042569 & 17252622 & Pers 3 78 (B) \\
\hline 0 & -235467 & -337200 & -92832 & $\begin{array}{c}\text { Persamaan 5 } \\
\text { (a- } B \text { ) }\end{array}$ \\
\hline \multicolumn{4}{|c|}{ Sumber : Sugiyono (2015: 280) } \\
\hline
\end{tabular}

Langkah berikutnya mencari persamaan (6) dengan cara mengalikan harga persamaan (4) dengan harga $b_{1}$ pada persamaan (5) yaitu (-235467), dan mengalikan harga persamaan (5) dengan harga $b_{1}$ pada persamaan (4) yaitu (-241430). Hasil dari perhitungan tersebut adalah sebagai berikut :

\begin{tabular}{|c|c|c|c|c|}
\hline $\mathrm{a}$ & $b_{1}$ & $b_{2}$ & $Y$ & Keterangan \\
\hline - & 56848797810 & 55444708089 & 10245169170 & $\begin{array}{c}\text { Pers } 4 \times(-235467) \\
=a\end{array}$ \\
\hline - & 56848797810 & 81410196000 & 22412429760 & $\begin{array}{c}\text { Pers } 5 \times(-241430) \\
=B\end{array}$ \\
\hline - & 0 & -25965487911 & -12167260590 & Persamaan 6(a-B) \\
\hline \multicolumn{5}{|c|}{ Sumber : Sugiyono (2015: 280) } \\
\hline
\end{tabular}

Untuk mengetahui nilai $b_{2}$ didasarkan pada persamaan (6) yaitu sebagai berikut :

- 25965487911. $b_{2}=-12167260590$

$\mathrm{b}_{2}=-12167260590 /-25965487911$

$\mathrm{b}_{2}=0.468$

Untuk mengetahui nilai $b_{1}$ didasarkan pada persamaan (5) dengan perhitungan sebagai berikut :

$$
\begin{aligned}
& -235467 b 1-337200 b 2=-92832 \\
& b_{1}=(-92832+(-337200 \times 0.468)) /-235467 \\
& b_{1}=(-92832+157809.6) /-235467 \\
& b_{1}=(-64977) /-235467 \\
& b_{1}=0.276
\end{aligned}
$$

Untuk mengetahui nilai a menggunakan persamaan (1) dengan perhitungan sebagai berikut :

$$
\begin{aligned}
& 78 a+4049 b_{1}+3963 b_{2}=4330 \\
& \mathbf{a}=\frac{4330-4049 b_{1}-3963 b_{2}}{78} \\
& \mathbf{a}=\frac{4330-4049 * 0.276-3963 * 0.468}{78} \\
& \mathbf{a}=\frac{4330-1117.524-1854.684}{78}
\end{aligned}
$$

$$
\begin{aligned}
& \mathbf{a}=\frac{1357.792}{78} \\
& \mathbf{a}=\mathbf{1 7 . 4 1}
\end{aligned}
$$

Dari perhitungan tersebut di atas telah diketahui nilai-nilai $a, b_{1}$, dan $b_{2}$ sebagai berikut :

$$
\begin{aligned}
& \mathrm{a}=17.41 \\
& \mathrm{~b}_{1}=0.276 \\
& \mathrm{~b}_{2}=0.468
\end{aligned}
$$

Dengan demikian persamaan regresi ganda linier untuk dua variabel yaitu gaya kepemimpinan dan jabatan fungsional perekayasa adalah :

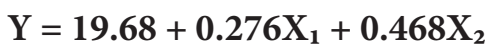

Dari persamaan tersebut diartikan apabila kinerja akan meningkat apabila gaya kepemimpinan dan karir jabatan fungsional perekayasa ditingkatkan. Apabila gaya kepemimpinan ditingkatkan menjadi 75 (nilai optimal), dan karir jabatan fungsional perekayasa juga ditingkatkan menjadi 75 , maka kinerja pegawai akan menjadi :

$$
\begin{aligned}
\mathrm{Y} & =19.68+0.276(75)+0.468(75) \\
\mathrm{Y} & =19.68+20.7+35.1 \\
\mathrm{Y} & =75.33
\end{aligned}
$$

Jadi nilai kinerja pegawai diperkirakan akan menjadi sebesar 75.33 .

\section{SIMPULAN}

Hasil uji hipotesis 1 (Diduga terdapat pengaruh positif dan signifikan secara parsial dari gaya kepemimpinan terhadap kinerja pegawai BBTA3-BPPT). Dari hasil perhitungan korelasi product moment sederhana diperoleh $\mathrm{r}_{\text {hitung }}=$ 0.203 dan hasil $t_{\text {hitung }}$ diperoleh nilai sebesar 2.446 dengan demikian dapat disimpulkan bahwa terdapat pengaruh positif dan signifikan dari gaya kepemimpinan terhadap kinerja pegawai, walaupun jika dilihat dari kualitas hubungan termasuk pada tingkat yang rendah. Dari hasil perhitungan koefisien determinasi bahwa pengaruh gaya kepemimpinan terhadap kinerja pegawai adalah sebesar $4.12 \%$ sisanya sebesar $95.88 \%$ ditentukan oleh faktor lain.

Hasil uji hipotesis 2 (Diduga terdapat pengaruh positif dan signifikan secara parsial dari karir jabatan fungsional perekayasa terhadap kinerja pegawai BBTA3-BPPT). Dari hasil perhitungan korelasi product moment sederhana diperoleh 
$\mathrm{r}_{\text {hitung }}=0.367$ dan hasil $\mathrm{t}_{\text {hitung }}$ diperoleh nilai sebesar 3.227 dengan demikian dapat disimpulkan bahwa terdapat pengaruh positif dan signifikan dari karir jabatan fungsional perekayasa terhadap kinerja pegawai walaupun jika dilihat dari kualitas hubungan termasuk pada tingkat yang rendah. Dari hasil perhitungan koefisien determinasi bahwa pengaruh karir jabatan fungsional perekayasa terhadap kinerja pegawai adalah sebesar 13,45 \% sisanya sebesar $86.55 \%$ ditentukan oleh faktor lain.

Hasil uji hipotesis 3 (Diduga terdapat pengaruh positif dan signifikan secara simultan gaya kepemimpinan dan karir jabatan fungsional perekayasa terhadap kinerja pegawai BBTA3-BPPT. Dari hasil perhitungan korelasi product moment sederhana diperoleh $\mathrm{r}_{\text {hitung }}=0.394$ dan harga $\mathrm{F}_{\text {hitung }}$ sebesar 5.923 dengan demikian dapat disimpulkan bahwa terdapat pengaruh positif dan signifikan antara gaya kepemimpinan dan karir jabatan fungsional perekayasa secara bersama-sama terhadap kinerja pegawai. Dari hasil perhitungan koefisien determinasi ada pengaruh positif dan signifikan dari gaya kepemimpinan dan karir jabatan fungsional perekayasa secara bersamasama terhadap kinerja pegawai adalah sebesar $15.52 \%$ sisanya sebesar $84.48 \%$ ditentukan oleh faktor lain.

\section{PENGHARGAAN}

Dalam kesempatan ini penulis juga ingin menyampaikan rasa terima kasih dan penghargaan kepada semua pihak yang telah ikut membantu dalam proses penelitian ini, antara lain Dr. Fadilah Hasim, B.Eng., M.Eng, selaku Kepala BBTA3-BPPT yang telah memberikan kesempatan kepada penulis untuk melakukan penelitian di BBTA3-BPPT. Kemudian Agus Basuki, S.Sos, M.Si, selaku Ka. Bagian Umum BBTA3-BPPT yang telah memberikan bimbingan dalam proses penelitian. Teman-teman Dosen Universitas Pamulang.

\section{DAFTAR PUSTAKA}

Adelina, BBR. Samsir Rambe. (2015). DasarDasar Manajemen. edisi ke 2. Bandung:
Angkasa.

Arikunto, Suharismi. (2012). Metode Penelitian Suatu Pendekatan Praktek. Jakarta: Rineka Cipta.

Bateman, S, Thomas. (2018). Kepemimpinan dan Kolaborasi Dalam Dunia Yang Kompetitif. Jakarta: Salemba Empat.

Hadari Nawawi, H. (2015). Manajemen Sumber

Daya Manusia. Yogyakarta: Penerbit Universitas Gajah Mada Press.

Handoko T. Hani. (2016). Manajemen Personalia dan Sumber Daya Manusia. Edisi Ke 2. Yogyakarta: Penerbit BPPE.

Hasibuan, S.P, Malayu. (2016). Manajemen Sumber Daya Manusia. Edisi Revisi. Jakarta: Bumi Aksara.

Pasolong, Harbani. (2018). Pemimpin Birokrasi. Jakarta: Penerbit Alfabeta

Heidjrachman Ranupanjono, Drs. (2019). Manajemen Sumber Daya Manusia I. Jakarta: Penerbit Universitas Terbuka.

Kartono, DR. (2018). Pemimpin dan Kepemimpinan. Jakarta: Penerbit Raja Grafindo Persada.

Peraturan Kepala Badan Pengkajian dan Penerapan Teknologi Nomor 013 Tahun 2015, tentang Organisasi dan Tata Kerja Balai Besar Teknologi Aerodinamika, Aeroelastika, dan Aeroakustika.

Keputusan Kepala Badan Pengkajian dan Penerapan Teknologi Nomor 015 Tahun 2016, tentang Petunjuk Teknis Jabatan Fungsional Perekayasa dan Angka Kreditnya. Mangkunegara, Anwar Prabu. (2017). Manajemen Sumber Daya Manusia Perusahaan. Bandung: PT. Remaja Rosda Karya.

Mangkunegara, Anwar Prabu. (2016). Evaluasi Kinerja SDM. Bandung: PT. Refika Aditama. Sondang P. Siagian. (2018). Manajemen Sumber Daya Manusia. Jakarta: Bumi Aksara.

Stephen P. Robbin. (2015). Prinsip-Prinsip Perilaku Organisasi. Jakarta: Edisi Indonesia, Erlangga.

Stephen P. Robbin. (2018). Perilaku Organisasi (Organizational Behavior). Jakarta: Edisi ke 8, Salemba Empat.

Sudjana. (2015). Metoda Statistika. Bandung: 
Edisi ke 5.

Sugiyono, Prof, Dr. (2015). Metode Penelitian dan Administrasi. Bandung: Alfabeta.

Sugiyono, Prof, Dr. (2018). Metode Penelitian Bisnis. Bandung: Alfabeta.

Thoha, Miftah. (2016). Perilaku Organisasi Konsep Dasar dan Perilakunya. Jakarta: Raja Grafindo Persada.
Thoha, Miftah. (2007). Kepemimpinan Dalam Manajemen. Jakarta: Rajawali Press.

Umar, Husein. (2015). Studi Kelayakan Bisnis. Jakarta: Gramedia Pustaka Utaman.

Wibowo, Prof, Dr, S.E., M.Phil. (2019).Manajemen Kinerja. Jakarta: Penerbit PT Raja Grafindo Persada. 